\title{
Hegemonic masculinity as a historical problem
}

\section{Ben Griffin, Girton College, Cambridge}

The history of gender is necessarily a history of power, whether it concerns power relations between men and women, between women, or between men. ${ }^{1}$ Power relations between men have long been a central theme of historical writing, but it is only in the last thirty years that they have been understood in gendered terms. The criminalization of male homosexuality before 1967 is one of the most striking ways in which the modern British state has sought to privilege some forms of masculinity over others, but laws regulating leisure practices (especially drinking) and family maintenance contributions have served the same purpose. The state has not only punished unacceptable masculinities, it has endorsed or rewarded more acceptable forms. The reform of the electoral system in the nineteenth century, for example, was explicitly intended to limit the vote to particular kinds of men: privileging fathers of families who had settled down and who paid their taxes. ${ }^{2}$ Informal sanctions have been no less responsible for differentiating between more and less acceptable ways of being a man, ranging from schoolboy taunts between jocks and nerds, to the 'rough music' with which nineteenth-century communities greeted men who had overstepped the accepted boundaries of male authority when they had beaten their wives. Power relations between masculinities have been a fundamental element of the gender order.

Since its development as a field of historical inquiry in the mid-1990s, the history of masculinity has demonstrated the enormous diversity of norms associated with being a man. And yet, one of the peculiarities of the history of masculinity in the Anglophone world is that discourses about masculinity have usually denied this diversity. Those seeking to exalt one conception of masculinity above others have rarely done so by accepting that their favoured 
model is one among many, but have more usually insisted that deviation from their preferred form is 'unmanly' or effeminate. ${ }^{3}$ In this trope there is only one true form of masculinity and as one approaches it one becomes more 'manly', while moving away from it entails the loss of 'manliness' or 'manhood'. There is no scope for acknowledging that different men in the same society might have different, equally valid, understandings of masculinity. This is a rhetorical manoeuvre of the first importance for studies of power: as R. W. Connell and James Messerschmidt have noted, 'Whatever the empirical diversity of masculinities, the contestation for hegemony implies that gender hierarchy does not have multiple niches at the top. ${ }^{4}$ Studying the operation of this rhetoric by examining how constructions of masculinity have defined themselves against 'effeminate' or 'unmanly' others has been a major preoccupation of historians. But such one-dimensional scales of manliness were not the only ideological apparatuses positioning masculinities in relations of power with each other. Nor is power a purely discursive phenomenon. How then are we to study historically the dynamics of power between competing models of masculinity in any given society?

The analysis of relations between multiple masculinities is most closely associated with the work of the Australian sociologist R. W. Connell. ${ }^{5}$ Despite detailed criticism by historians, Connell's approach remains the central point around which studies of masculinity navigate because no alternative framework has delineated so clearly the significance of power relations between masculinities. The challenge for historians is to find ways of studying these power relations historically. This article will offer a critical reading of Connell's model and suggest that elements of it can be reframed in a way that will shed useful light on patterns of change in gender history more effectively than rival approaches. It will do so by examining how historians of early modern and modern Britain have grappled with Connell's challenge before suggesting a way forward. 


\section{Hegemonic masculinity and the history of masculinity}

The most obvious achievement of historians of masculinity over the last two decades has been to assemble a series of case studies demonstrating changes in the qualities associated with being a man. In the case of British history, for example, we now have histories charting the rise and fall of the 'polite' gentleman in the eighteenth century, the emergence of new codes of 'manliness' in the nineteenth century, and the changing fortunes of domestic masculinities. ${ }^{6}$ Having come this far, historians have begun to grapple with the question of what to do with these accumulated case studies. How can changes in the history of masculinity be explained? ${ }^{7}$ Early models of change resting on the notion of a 'crisis of masculinity' soon became unsustainable as an implausible picture emerged of 'men interminably in crisis', but what will take their place ${ }^{8}$ In 1994, John Tosh proposed an approach based on studying how male identities were shaped by the changing balance between home, work and all-male associations; once historians showed that gender was omnipresent, however, the justification for privileging those three loci fell away. ${ }^{9}$ Underpinning many of the discussions about the state of the field has been a debate about the limitations of cultural history methodologies and how to reconcile 'work on cultural codes and representations, on men's social relations with each other and with women, and on subjective experience. ${ }^{10}$ Perhaps most importantly, historians have found themselves confronted by the question of how changes in the history of masculinity have related to persistent inequalities between men and women - a point raised forcefully by recent efforts to rehabilitate the term 'patriarchy'. ${ }^{11}$

In this context it is easy to see why historians have been so interested in R. W. Connell's model of gender relations, first put forward in 1987 and reformulated in 2005 with James 
Messerschmidt. ${ }^{12}$ Connell's model offers a way of analysing the power relations that exist between varieties of masculinity. Connell posits that there will be a form of masculinity that is accorded greater cultural and political legitimacy than others - a 'hegemonic masculinity'. This should not be understood as a static character type but as a historically contingent and variable form. Moreover, 'hegemony' does not refer to a position of achieved total dominance but to 'an indefinitely deferred aspiration to control social encounters by those with sufficient material, practical and ideological resources to rehearse and maintain relational capacities. ${ }^{13}$ Historical study of dominant codes of masculinities has shown them to be highly complex, fluid, and full of contradictions; but the fact that one can identify a code, even if it contains internal contradictions, underlines the fact that such codes do constitute identifiable units of analysis. ${ }^{14}$

Connell argues that other forms of masculinity exist in one of three relationships to the hegemonic form: subordination, complicity and marginalisation. Subordinate masculinities are those denied legitimacy (for much of history in the West, queer masculinities offer a good example). Complicit masculinities are those which do not conform to the hegemonic model but which do not challenge it; indeed men performing complicit masculinities may support the gender order because they are still able to reap the 'patriarchal dividend' secured by the hegemonic form. Finally, the category of marginal masculinities reflects the complexity of power relations generated by the intersection of gender with other axes of social stratification like ethnicity or class, which lead to the marginalisation of particular groups. Connell gives the example of black men in the USA, who might perform hegemonic masculinities without being accorded the recognition or authority that might otherwise be available to them.

The most ambitious element of Connell's model is the claim that this structure of power relations between masculinities ('the social organisation of masculinities') underpins the subordination of women. 'Hegemonic masculinity', Connell argues, 'can be understood as the 
configuration of gender practice which embodies the currently accepted answer to the problem of the legitimacy of patriarchy, which guarantees (or is taken to guarantee) the dominant position of men and the subjection of women. ${ }^{15}$ In this model then, patriarchy is not simply a process by which men dominate women: instead, relationships between men and women are determined by sets of relationships between masculinities. Connell initially examined this sexual inequality in terms of three different but related structures: relations of power, production and cathexis (emotional attachment); she later added symbolic relations to the model. ${ }^{16}$ By locating gender relations within these structures Connell acknowledges that the gender order is not an autonomous system, but one that emerges from the interactions between a number of different social relations. ${ }^{17}$

One of the attractions of this model for historians is that it acknowledges that the 'dominance of men and the subordination of women constitute a historical process, not a selfreproducing system. ${ }^{18}$ Connell's model is rooted in an appreciation of history, even if historians might wish to challenge her account of the creation of modern masculinities. ${ }^{19}$ The history of masculinity, from Connell's perspective, is not a sequential catalogue of ideal types of masculinity but a history of changes in a set of structural relationships between competing models of masculinity. A history of the social organisation of masculinities would be interested in moments when one form of hegemonic masculinity was replaced by another, such as the sudden privileging of western modes of dress and behaviour among social elites in Japan after the Meiji restoration. ${ }^{20}$ Michael Kimmel's history of how the figure of the 'self-made man' displaced the 'genteel patriarch' and the 'heroic artisan' in American culture is a history along these lines, as is Karen Hagemann's account of the rise of a patriotic militarized masculinity in nineteenth-century Prussia. ${ }^{21}$ This kind of history would also be interested in moments when a complicit masculinity was translated into a subordinate or marginal position (as happened in the case of monks after 
the Reformation in Britain), or when a subordinate or marginal masculinity was moved into a complicit position (as happened with the enfranchisement of working-class householders in Britain in 1867, or the partial decriminalization of homosexual acts between men in Britain in 1967). ${ }^{22}$ The gender order might from time to time exhibit 'crisis tendencies', but Connell's formulation rejects explanations based on a 'crisis of masculinity' because in her model masculinity is not a system but 'a configuration of practice within a system of gender relations'; and we 'cannot logically speak of the crisis of a configuration' ${ }^{23}$

Connell's model has become the theoretical touchstone for numerous histories of masculinity, yet few historians have found it satisfactory. Unfortunately, despite its shortcomings, even the most sophisticated rival models have not been able to match the clarity with which Connell anatomises power relations between masculinities. ${ }^{24}$ Nevertheless, the objections to Connell's model are compelling and must be addressed if historians are to develop a more satisfactory account of power relations between men. The next section of the article will present seven different objections to the theory of hegemonic masculinity; the following sections will then suggest an analytical framework capable of accommodating them.

\section{A problematic model}

Connell's most incisive critic has been John Tosh, who argues that it is difficult to relate the gendered structure of power that Connell describes to other structures of power such as class, or denominational affiliation. Connell was certainly not unaware of the challenges of intersectionality when formulating the theory. From the outset she has been clear that any one masculinity, 'as a configuration of practice, is simultaneously positioned in a number of structures of relationship, which may be following different historical trajectories. ${ }^{25}$ To this extent she would 
surely agree with Tosh that masculinity 'is better seen as one of a number of hierarchical principles which operate together to define the lineaments of the social order'. ${ }^{26}$ However, it is not clear that the concept of 'marginalisation' - which is used to refer to 'the relations between the masculinities in dominant and subordinated classes or ethnic groups' - can adequately describe the effects of class and race, and throughout it appears to occupy a subordinate role to gender in the analysis. ${ }^{27}$ Tosh is surely correct to argue that 'it is never convincingly demonstrated why patriarchy should take precedence over all other structuring principles, to the extent that Connell affirms.' It follows from this that it may be misleading to explain hierarchies among masculinities simply in terms of the functional imperative to maintain the subjection of women: other principles may be at work. ${ }^{28}$ The point is well made, and raises the question of just how strong a claim Connell intended to make when defining hegemonic masculinity as 'the configuration of gender practice which ... guarantees (or is taken to guarantee) the dominant position of men and the subjection of women.' ${ }^{29}$ When faced with functionalist explanations in history, caution is necessary. ${ }^{30}$ Although historians might wish to show empirically how hierarchies among masculinities contributed to the oppression of women, any connection between the two must be taken as contingent and not as dictated by functional imperatives. As Jeff Hearn has argued, explaining the hegemony of particular forms of masculinity is not the same as explaining the hegemony of men. ${ }^{31}$

The second objection to Connell's model concerns its treatment of femininity. Connell argued in her 1987 book Gender and power that 'the concentration of social power in the hands of men leaves limited scope for women to construct institutionalized power relationships over other women.' This means that 'no pressure is set up to negate or subordinate other forms of femininity in the way hegemonic masculinity must negate other masculinities.' For this reason she labels the culturally dominant pattern of femininity not 'hegemonic' but 'emphasized 
femininity'.32 Empirically such claims are difficult to substantiate; power relationships between forms of femininity have surfaced frequently in studies of class hierarchies. ${ }^{33}$ Mimi Schippers has argued that there can be a form of 'hegemonic femininity', which she defines as consisting of 'the characteristics defined as womanly that establish and legitimate a hierarchical and complementary relationship to hegemonic masculinity and that, by doing so, guarantee the dominant position of men and the subordination of women. ${ }^{34}$ This of course is open to Tosh's objection that there is no a priori reason to grant causal primacy to the functional requirements of patriarchy among a range of other possible stratifying principles; nevertheless, it does draw attention to power relations between women that are not given sufficient attention in Connell's work. In order to maintain the dominance of a 'hegemonic femininity', Schippers argues, other forms of femininity have to be policed.

'Practices and characteristics that are stigmatized and sanctioned if embodied by women include having sexual desire for other women, being promiscuous, "frigid", or sexually inaccessible, and being aggressive. These are characteristics that, when embodied by women, constitute a refusal to complement hegemonic masculinity in a relation of subordination and therefore are threatening to male dominance. For this reason they must be contained. ${ }^{35}$

Schippers describes these illegitimate femininities as 'pariah femininities', rejecting the term 'subordinate' because 'they are deemed, not so much inferior, as contaminating to the relationship between masculinity and femininity.' Although these pariah femininities frequently involve qualities associated with masculinity 'they are necessarily and compulsively constructed as feminine when enacted by women; they are not masculine. ${ }^{36}$ It is doubtful whether this scheme of hegemonic and pariah femininities exhausts the range of power dynamics.

As soon as one modifies or rejects Connell's analysis of femininity, her theory of masculinity becomes more difficult to sustain as it drastically increases the number of variables that the model needs to accommodate. What relationships exist between complicit masculinities 
and pariah femininities? Are there power relationships between marginal masculinities and particular kinds of pariah femininity? If so, what are the implications of those relationships for hegemonic or complicit masculinities? Very quickly the model generates such complexity that it ceases to function.

These two objections to the model - that it is difficult to relate gender hierarchies to other structures of power, and that the relationships between the structures of power between men and those between women are under-theorised - are both cause and effect of a persistent ambiguity about the precise mechanisms that are used to secure the hegemonic status of a particular form of masculinity. This is the third major objection to Connell's model. The ambiguity persists despite the sophistication of Connell's analysis of how the three gendered structures of power, production and cathexis are instantiated in the gender regimes of the state, the family and the street. ${ }^{37}$ For this reason, the theory is vulnerable to all of the criticisms that have been levelled at the concept of hegemony since Gramsci developed it to analyse the reproduction of capitalist ideology. ${ }^{38}$ Indeed, there have been efforts by some theorists to place Connell's model on a more rigorously Gramscian foundation. ${ }^{39}$

A fourth criticism of Connell's model follows from this critique of 'hegemony'. Historians like Alex Shepard argue that Connell's model implies a greater degree of stability in the gender order than is warranted by the evidence and over-simplifies the range of power dynamics at work. 'Conflicting meanings of manhood', she has argued, 'are not always easily categorized as subordinate, complicit or marginalized in relation to patriarchy, since they were often articulated in terms of active resistance. In addition, alternative meanings of manhood exerted an autonomous authority, independent of patriarchal manhood, and not solely defined in its shadow. ${ }^{40}$ She has therefore helpfully replaced the term 'hegemonic masculinity' with 'normative masculinity' and has replaced the categories of complicit and marginal masculinities with two new 
categories: 'antipatriarchal manhood' and 'alternative codes of manhood'. How useful are these two new categories?

The idea that there were 'alternative codes of manhood', which were 'independent from but not necessarily articulated in direct tension with patriarchal norms' is problematic, because it is not clear that these alternatives genuinely pose a threat to Connell's classificatory scheme. Even if, from the perspective of early modern men, these codes were not defined in relation to patriarchal manhood, from the perspective of the historical sociologist they still occupied a position relative to it. If those alternative codes posed no threat to patriarchal manhood then they can accurately be described as either complicit in the gender order or marginal to it. That is not to say that those codes should only be studied in relation to the dominant model, but in the context of the broader gender order then Connell's point stands. The concept of 'antipatriarchal manhood', on the other hand, does require a substantial modification of Connell's model. Shepard identifies 'deliberate countercodes of resistance adopted in flagrant rejection of patriarchal imperatives' ${ }^{41}$ These codes were neither effectively subordinated to the normative model nor marginalized, and failed to perform a complicit role. This new category usefully draws attention to the fact that the 'hegemonic' or 'normative' status of particular masculinities did not always rest on a completely successful suppression of alternatives: they were frequently contested and rarely secure. Complicity, marginality and subordination, in short, do not exhaust the range of possible positions that masculinities might occupy relative to a normative model: active resistance must be added to the list. ${ }^{42}$

The fifth problem with Connell's model is what I shall refer to as the problem of scale. Put simply, within what kind of social formation is hegemony taken to operate? Does hegemonic masculinity represent the dominant form of masculinity within 'the West', a particular nation state, a region, a city, a class, or a religious denomination? Connell and Messerschmidt 
acknowledge this as a problem and in their 2005 article they distinguish between global, regional and local arenas for the creation of hegemonic masculinities. This approach, they argue, 'casts some light on the problem of multiple hegemonic masculinities' revealed by empirical research like Shepard's work on early modern England. ${ }^{43}$ This raises new questions: does the same pattern of hegemony, subordination, complicity and marginalisation occur at each level of scale, like a fractal geometry recursively reappearing at different levels of magnification ${ }^{44}$ Or does the structure of power relations change at each level of analysis? In settling this problem of scale, an important question for historians is whether it is meaningful to speak of cultural hegemony when describing periods before the era of mass communication. For example, when we consider nineteenth-century Britain, we find that working-class identities were still rooted in particular localities that shared distinctive oral and written dialects, so it is difficult to speak about a shared national working-class culture. ${ }^{45}$ This regional diversity produced a multiplicity of competing sets of gender norms that circulated before the emergence of a mass culture. ${ }^{46}$ For this reason, it will be suggested later, the solution to the problem of scale must be rooted in more than just geography - the appropriate frame of analysis must be determined in part by an understanding of the mechanisms and technologies through which power relations might be established in past societies.

The sixth problem with Connell's model concerns ontology. Put simply, where are the men performing hegemonic masculinity ${ }^{47}$ As Connell has noted, hegemonic images of masculinity 'need not correspond to the actual characters of the men who hold most social power'. 'The public face of hegemonic masculinity is not necessarily what powerful men are, but what sustains their power and what large numbers of men are motivated to support.' The bearers of hegemonic masculinity are frequently fantasy figures. ${ }^{48}$ Consequently, the defence of hegemonic masculinity rests on 'a fairly convincing corporate display of masculinity' by the social 
elites rather than the ability of individuals to live up to the ideal. ${ }^{49}$ This idea deserves closer scrutiny because it means that whereas those masculinities identified as complicit, subordinate and marginal are defined by sets of practices performed by identifiable groups of men, hegemonic masculinity is not: it may be a configuration of practice that no one need practise. At this point the category of 'complicit masculinities' threatens to swallow the rest of the model, as even the most powerful men are frequently seen to fall short of the hegemonic ideal in practice. In this reading masculinity becomes, in the words of Robert A. Nye, 'a telos that men experience as a necessary but permanently unattainable goal. ${ }^{50}$ As Christopher E. Forth and Bertrand Taithe have written, as a lived experience, 'masculinity is always subject to scrutiny, lapses, and failed performances' ${ }^{51}$ This gap between the hegemonic ideal and the practice of socially privileged men raises in an acute form the concerns about the limitations of cultural history that have characterised gender history in recent years. ${ }^{52}$ Is the history of masculinity to be the history of representations or practices? No one has been more eager than Connell to stress that masculinity is not purely a discursive phenomenon, but a 'configuration of practice' with the emphasis placed 'on what people actually do, not on what is expected or imagined. ${ }^{53}$ And yet her account of hegemonic masculinity is far more successful as an account of ideals, fantasies, and desires than as a description of social practices. Connell has attempted to respond to this, writing that 'Although any specification of hegemonic masculinity typically involves the formulation of cultural ideals, it should not be regarded only as a cultural norm. Gender relations are also constituted through non-discursive practices, including wage labor, violence, sexuality, domestic labor, and childcare, as well as through unreflective routinized actions. ${ }^{54}$ But, as Mimi Schippers has argued, this argument confuses gender relations with masculinity. ${ }^{55}$ The ontological problem is therefore not adequately addressed: the study of hegemonic masculinity threatens to dissolve into a study of myths, rather than a study of actual men. 
The final problem with Connell's model is what I will refer to as the situational identity problem. This is a problem revealed by Alex Shepard's work on early modern manhood, namely that individual men do not continually perform the same masculinity. As Shepard puts it, 'one man might conform to more than one category not only over the course of a lifetime but also over the course of a single day. ${ }^{\prime 56}$ In other words, a man who was a respectable patriarch at home might not embody the dominant model of masculinity at work, and in the pub at weekends might even perform antipatriarchal masculinities; the 'polite gentleman' may not have been polite in all contexts. ${ }^{57}$ The same point has been made by Philip Carter, who has written that 'manliness was an essential but also complex and fluid identity, configured differently with respect to the sex, class and nationality of one's companions, and the geographical location and time of day when meetings took place. ${ }^{58}$ According to the social psychologists Margaret Wetherell and Nigel Edley, masculinities are adopted strategically according to the situations that men find themselves in. ${ }^{59}$ Taking this approach goes beyond simply recognising that the boundaries between 'complicit' and 'subordinate' masculinities are porous: it transforms the heuristic value of Connell's model. If men move between masculinities depending on context then it will be impossible to populate the categories of Connell's model with stable groups of real men; 'hegemonic', 'complicit', 'subordinate' and 'marginal' masculinities become principally categories of cultural rather than social description. The political consequences of this analysis are important. Accepting that individual men can move between masculinities drives a wedge between the study of hegemonic masculinities (understood as cultural norms) and the study of men's power over other men and over women as it was manifested in social interactions between real individuals. ${ }^{60}$

The situational identity problem creates two further difficulties. The first of these concerns agency: how free were men in the past to adopt different masculinities? The ability to move between masculinities might be seen as an advantage - an adaptive capacity facilitating 
social mobility. But what were the constraints on such movement? Could an aristocratic man in the 1910 s perform the kinds of working-class masculinity found in the Glasgow shipyards? The second problem concerns subjectivity. How are we to understand the way in which individuals moved between forms of masculinity? Are masculinities like clothes that one can put on or take off at will? To treat them as such would ignore the emotional investments that individuals make in the cultural materials that they use to create a self. ${ }^{61}$

These are seven powerful objections, so why not abandon Connell's model? Because to do so runs the risk of leaving us with a history of masculinity that is little more than a parade of types of masculinity with no way of analysing power relations between them and no way of thinking about the relationship between the history of masculinity and the history of patriarchy. Contests between competing models of masculinity were important in securing the subjection of both men and women. This is why historians have been unable to break free of their fascination with 'hegemonic masculinity', so it remains to see what can be salvaged from Connell's model and how it can be put to work.

\section{An alternative framework}

The first step involves addressing the problem of scale, so that we can identify the social formation within which it is appropriate to speak of a hegemonic masculinity. Connell and Messerschmidt's distinction between global, regional and local hegemonies is insufficiently precise and, as we have seen, is insufficiently attentive to the technologies and mechanisms through which power relations are produced. A more useful approach is to base our analysis around what Simon Szreter has called 'communication communities'. This concept recognises the variegated and uneven dissemination of particular sets of cultural norms and relates this to the 
historically specific mechanisms of socialization through which those norms were propagated. ${ }^{62}$ In nineteenth century Britain, for instance, the masculinity of working-class boys was shaped by their experiences in dame schools, in their parents' homes, on street corners and in work environments. The result was localised communities sharing the same norms, values and expectations, which were very different to those found, not only in middle-class communities, but also to those found in working-class communities in other parts of the country. As Bertand Taithe has remarked about nineteenth-century France, 'masculinity took different forms from class to class and place to place. ${ }^{63}$ Work on fertility practices and childrearing, have shown that workingclass gender politics in Britain were profoundly influenced by local norms and exhibited substantial regional variations. ${ }^{64}$ In contrast, the middle and upper classes participated in a more unified and genuinely national communication community, reading the same novels and periodicals and attending the same educational institutions that inculcated a shared set of values and practices that were far less regionally specific. ${ }^{65}$ Communication communities then are defined not simply in terms of a set of shared norms, but by shared engagement in the mechanisms through which individuals were socialised into particular sets of norms, values and expectations. We can see some ethnic or immigrant communities as communication communities in this sense. ${ }^{66}$ With the development of global empires, mass culture and improvements in technology one might also point to the growing significance of global communication communities, as demonstrated by the increasing global uniformity of elite male clothing in the nineteenth century. ${ }^{67}$

It was in these communication communities that boys learned what it meant to be men. It was through these distinctive patterns of socialization that members of a community developed what Pierre Bourdieu has termed habitus - 'systems of durable, transposable dispositions', the practical knowledge that structures social activity in a way that is "regulated" and "regular" 
without in any way being the product of obedience to rules'. ${ }^{68}$ The habitus shapes people's 'bearing, posture, presence, diction, and pronunciation, manners and usages' and gives them the practical knowledge they need to participate in social life, adapted to the conditions in which this knowledge was acquired. ${ }^{69}$ At a fundamental level these dispositions are gendered. ${ }^{70}$ Consequently, aristocratic masculinity in the nineteenth century was as much a matter of body language as of wealth. There was a whole grammar of precisely observed gestures and postures that held meaning for the trained observer: Lady Colin Campbell, for example, claimed to be able to identify a gentleman by his walk. ${ }^{71}$ This requires a further analytical step, because it will be clear from this example that communication communities cannot solely be understood as loci for socialization; they must also be seen as communities of interpretation - the locus in which the semiotics of a particular habitus could be understood. That is simply to say that the significance of a gentleman's walk may have been lost to one not brought up in the same social circles as Lady Colin Campbell, just as the significance of aspects of working-class culture were frequently misinterpreted by well-intentioned lady visitors. Communication communities were social formations in which particular forms of masculinity were given meaning.

Thinking in terms of communication communities allows us to develop a more refined analysis than crude distinctions between 'middle-class' and 'working-class' masculinities allow us to do, whilst acknowledging the centrality of class and social experience to the formation of gender identities. It also allows us to make meaningful generalisations about the reach or 'throw' of particular discourses. ${ }^{72}$ In this way it is possible to respond to Karen Harvey and Alexandra Shepard's call for a clearer sense of the social purchase of cultural models of masculinity. ${ }^{73}$ As Graham Dawson has noted, the particular repertoires of forms of masculinity available to individuals as they construct a sense of self are limited. Consequently, socialization within a particular communication community (or, as he puts it, a 'cultural circuit') places limits on 'the 
available possibilities for a masculine self in terms of the physical appearance and conduct, the values and aspirations and tastes and desires that will be recognized as 'masculine' ${ }^{74}$ These limits can be historicized. Moreover, by placing at the centre of analysis the mechanisms by which norms are propagated (such as schools, clubs, or newspapers), this approach allows us to study with greater precision how particular patterns of hegemony were created and sustained historically.

These communication communities also operated as the sites within which certain processes of authorisation took place, so that greater legitimacy was conferred on some forms of masculinity than others. In nineteenth-century Britain this occurred through a range of discursive and institutional practices, ranging from the role of the elite public schools in promulgating particular conceptions of manliness among the governing classes, to the ways in which neighbourhood gossip and rough music established the boundaries of respectable working-class masculinity among the poor. ${ }^{75}$ It is therefore meaningful to speak of hierarchies of masculinities being generated within communication communities, with normative models of masculinity emerging and other models occupying positions relative to them.

The masculine qualities prized in one communication community might be valued differently in another, so that hierarchies established between different forms of masculinity might vary between communication communities. The dominant model of masculinity in a nineteenth-century south Wales mining town, where there were few opportunities for female labour, might not have enjoyed the same prestige in a Lancashire mining town, where it was more common for women to contribute to household earnings. For this reason, it is difficult to generalise about hegemonic forms of masculinity that spanned different communication communities. For example, Matthew Gutmann's study of Mexico City in the 1990s found that working-class men often participated in childcare and did not lose status by doing so; men of the 
higher classes, on the other hand, still insisted on a more rigid sexual division of labour in which mothers did all of the physical care and nurturing. ${ }^{76}$ That is to say that forms of masculinity valued in one communication community might be completely marginal to the power structures in another. This goes a long way towards explaining Shepard's empirical finding that there were 'alternative' models of masculinity that appear not to be defined in relation to the dominant masculinity. The presence of such alternative masculinities is only inconsistent with Connell's model if it assumed that there is only one hegemonic masculinity spanning a whole society (the problem of scale). It is more productive to see a multiplicity of social formations coexisting within the same society, each with its own structuring principles. A form of masculinity that is hegemonic, subordinated or complicit within one communication community, when viewed from another communication community, might indeed appear as an 'alternative' masculinity constructed with no reference to the hegemonic form dominant in that second community.

We can go further than merely suggesting that different communication communities existed side by side. Communication communities might overlap or be nested inside one another. For example, Victorian men whose gender identities had been forged by the distinctive institutions of the governing classes, like the public schools, may also have been influenced by participation in other communication communities with distinctive institutions, practices and hierarchies of masculinity, like the army or the bar. Individuals who participated in several overlapping communication communities had to negotiate potentially conflicting identities, loyalties and values. For example, Michael Roper's study of British business management since 1945 describes the culture clash that occurred when middle-class managers, who had grown up in a communication community that valued formal qualifications, had to interact with men on the shop-floor who came from working-class communication communities that valued academic training very differently. One senior manager felt that 'if you weren't running around hitting bits 
of iron with hammers or wielding a spanner, then you weren't a man. ${ }^{77}$ The same problem was experienced in reverse by managers with working-class origins: the confident masculinity that they performed on the shop floor took on different meanings when transposed into a managerial culture that operated according to the norms of a different communication community. Consequently, a skilled technician entering management found himself battling against 'an ingrained feeling that his superiors in the workplace were somehow naturally more intelligent' and that 'authority lay with the gentleman'. ${ }^{78}$

If this approach addresses the problem of scale and allows us to be more precise about how certain forms of masculinity attained a normative status, it still proceeds on the basis that masculinity should be treated as a set of norms or ideals. The ontological problem remains: hegemonic masculinity is an ideal that does not necessarily describe any actual men. Perhaps we should just accept the gap between representation and reality and treat it as an opportunity for new kinds of analysis rather than a problem to overcome. The possibilities of such an approach can be seen in the work of the medievalist Simon Yarrow, who has suggested that we re-configure hegemonic masculinity as iconic masculinity. ${ }^{79}$ Two features of Yarrow's analysis mark it out as distinctive. First, he draws attention to the interpretative labour required to make sense of iconic masculinities. The efforts that men make to appear 'manly' have to be recognised by others if they are to be successful. Therefore, 'the interpretative labour of real women and other men in response to embodied male material display ... was socially important. ${ }^{80}$ This reflects the point made above that communication communities need to be seen as communities of interpretation. Second, and most importantly for this argument, he draws attention to the work that was required of men in order to appropriate the images associated with powerful forms of masculinity. For Yarrow, the term iconic masculinity 'is meant to encapsulate the affective efforts of elite males to reproduce the likeness of a hegemonic position, and the role of the viewer in recognising, 
reading and responding to that likeness.' Therefore a 'history of masculinities might usefully recast hegemonic masculinities in terms of iconic capacities and the ability of individuals, male or female, to affect, reject, usurp or take secondary advantage of these capacities. ${ }^{\prime 81}$

This is a valuable suggestion which forms the core of a response to the ontological problem. The argument so far has suggested that it is possible to identify communication communities in which particular models of masculinity circulate and are invested with varying amounts of authority or prestige. The next stage of the argument is to connect the cultural and social histories of masculinity by suggesting that historians of masculinity ought to direct their attentions towards the historically specific opportunities, mechanisms or techniques that enabled individuals to identify themselves with those normative models. In other words, what historically specific solutions were available to men that allowed them to close the gap between the cultural ideal and the practice of masculinity? That is to say that the dominance of the 'polite gentleman' or the 'manly' Victorian paterfamilias over other forms of masculinity was a dominance attained in the realm of culture: a different kind analysis is required to identify what men needed to do to be seen as 'polite gentlemen'. If identity is something that is constantly being produced, 'which is never complete, always in process', then historians of gender can profitably focus on the historical specificity of the techniques, technologies and resources that people in the past brought to this task. $^{82}$

This attention to how men attempted to bridge the gap between ideal and practice might be thought of as a history of the practical politics of complicity. The ontological problem means that any quest to find men who embody hegemonic masculinity may prove fruitless. We can get around this if we accept that the source of authority a man possesses within a particular social formation might be not the possession of a particular set of attributes, but access to mechanisms, techniques and opportunities that enable him to identify with those attributes or to pass himself 
off as possessing that set of attributes. ${ }^{83}$ The dominant social group will not be those who embody the normative ideal, but those who can most plausibly present themselves as doing so. For example, in the Victorian House of Commons, many of the most prominent defenders of the patriarchal order fell far short of contemporary ideals of masculinity: the most vocal antisuffragists in parliament were mummy's boys, henpecked husbands, or lifelong bachelors, none of whom could be held to live up to the hegemonic ideal. Their vocal and very public antisuffragism should be seen as an attempt to construct public masculinities that went some way towards insulating them from charges of 'unmanliness'. The adoption of particular clothing, body language and manners, engaging in leisure pursuits like hunting that required overt displays of physical robustness and courage, and the ostentatious deployment of a language of chivalry, allowed men to align themselves with an ideal of gentlemanliness, even though in their private lives they might fall short of the expected standard. ${ }^{84}$ This approach avoids treating masculinity solely in terms of cultural representations and instead draws our attention to the social practices that underpinned the performance of masculinity. It focuses precisely on the connections between the cultural and social histories of masculinity. It acknowledges that an understanding of gender as performative needs to be accompanied by a recognition that an individual's ability to undertake a particular gender performance requires access not only to the relevant script, but also access to the correct props and to an audience capable of understanding that performance. ${ }^{85}$

The mechanisms, techniques or opportunities available to men to associate themselves with the dominant form of masculinity in their communication community changed over time and are therefore amenable to historical study. Fathering many children, for example, was once seen as an indicator of virility and a way of laying claim to the status of paterfamilias, but by the second half of the twentieth century in Britain it had come to be seen as a sign of uncontrolled sexual appetites and had become a source of shame. ${ }^{86}$ Smoking and driving have similarly been activities 
that have allowed men to identify themselves with particular forms of masculinity, but the cultural meanings of those activities have changed considerably as women have, in Britain at least, been permitted to take up those pursuits. ${ }^{87}$ An alternative example might be the rise and fall of student duelling societies in Germany, which for a particular period of history provided young men, like the young Otto von Bismarck, with a way of publicly demonstrating a form of 'aggressive and quarrelsome masculinity' that was accorded prestige within some communication communities: indeed, Bismarck fought 25 duels in three semesters. ${ }^{88}$ Similar opportunities were presented by the volunteer corps in early nineteenth century Britain, which attracted young men who were 'brash, eager, hungry for a fight ... and desperately concerned not to seem a coward in the eyes of friends and lovers. ${ }^{89}$ The importance of work as a means by which men were able to identify with particular forms of masculinity is a seriously under-researched subject, but its significance can be seen from the fact that when work was withdrawn, as happened in the depression of the 1930s, the experience was described as emasculating. ${ }^{90}$ Equally, the strenuous opposition to admitting women to the professions in the nineteenth century indicates how important new forms of professional qualification were to specifically male identities..$^{91}$ The growth of 140 new qualifying associations for the professions between 1880 and 1970 allowed those men who could obtain qualifications to identify themselves with prestigious masculinities in a way that had not been possible earlier. ${ }^{92} \mathrm{~A}$ different kind of opportunity to associate oneself with dominant forms of masculinity was available to the generation that had fought in World War Two; this was not something that was available to later generations in the UK, especially after the abolition of callups to national service in 1960. In 1977 around two-thirds of British chief executives had done some kind of military service, and Roper has identified 'a belief among the post-war generation [of] men that they were superior men' by virtue of their military experience. ${ }^{93}$ Later generations would have to find different ways of identifying themselves with desirable forms of masculinity. 
To this extent, there can be a generationally dynamic politics of masculinity within a communication community even when there is continuity in the culturally dominant ideal. The important point is that these changes indicated not a new ideal of masculinity, but changes in the availability of mechanisms that men could use to associate themselves with existing ideals.

Most importantly, access to such mechanisms, techniques or opportunities was not distributed equitably. ${ }^{94}$ The fact that certain men had different levels of material and cultural capital meant that some men were better placed to associate themselves with normative or iconic masculinities than others. For example, those who could not afford the cost of male grooming products or new clothes, or who lacked access to washing facilities, might have found it difficult to perform certain forms of masculinity; fathers unable to support their families' financial needs were unable to lay claim to the prestige attached to the male breadwinner; and the status of the polite gentleman was not available to those without a modicum of education. This recognises the force of Pierre Bourdieu's model of social stratification based on inequalities of financial, cultural and symbolic capital but, in the light of the preceding discussion, it is important to recognise that the dominance of particular norms and values are subject to a greater degree of contestation than Bourdieu's model assumes. ${ }^{95}$

The metaphor of capital will only take us so far, because the ability to perform particular masculinities was also constrained by men's bodies: physical frailty, deafness or failing eyesight, perhaps as a result of ageing, placed limits on the repertoire of masculinities that a man could perform. ${ }^{96}$ These limits could sometimes be overcome, as in the celebrated cases of Henry Fawcett, the blind Cambridge don who serves as postmaster general in Gladstone's second ministry, and Arthur Kavanagh, a Conservative Irish MP between 1866 and 1880, born with severely under-developed arms and legs. In order to carry out his responsibilities, Fawcett employed amanuenses and servants. Kavanagh had an ingenious mechanical wheelchair and a 
servant to carry him to his seat in the House of Commons; he revelled in ostentatious displays of virility, like riding fearlessly to hounds in a special saddle. Through such means these men were able to perform the same masculinities as the temporarily non-disabled, but such physical and financial support was not available to all.

Bodies operated as constraints on the available range of masculinities in more subtle ways as well, because the habitus is more than a set of tastes and attitudes: it also shapes the body. As Connell remarks, 'The social definition of men as holders of power is translated not only into mental body-images and fantasies, but into muscle tensions, posture, the feel and texture of the body. ${ }^{\prime 97}$ Michael Roper's study of British managers found that the prevailing "cult of toughness" 'does not confine itself to the language which industrial managers use to describe their work; it is also conveyed in posture, gestures, facial expressions, and movements. ${ }^{98}$ In other words, men are socialized into sets of bodily practices that have varied over time and between communication communities. ${ }^{99}$ These dispositions are difficult to change and this operates as a further constraint on the available repertoire of masculinities that an individual can perform. This can be illustrated by the case of Alexander Macdonald, a working-class member of parliament in the 1870 s, who used to stand far on the floor of the House of Commons 'oscillating from side to side as if he were training for the office of pendulum, and rubbing himself about the waist with his right-hand'. The explanation for this fidgeting, said one observer, was his humble background, which meant that 'the man is ill at ease in the company in which he finds himself, and really does not know what to do with his hands, which, under such circumstances, are always a prime difficulty. ${ }^{\prime 100}$ For men who had not grown up in the corridors of power, bodily awkwardness frequently betrayed the fact that they did not belong. ${ }^{101}$ Elite masculinities were literally embodied in distinctive bodily practices, and that this placed obstacles in the way of men freely performing any form of masculinity that they wished. 
The historical study of power and masculinity is therefore the study of a four-fold operation. First, there is the process of cultural contestation whereby certain forms of masculinity are valorised, producing patterns of subordination, complicity, marginalisation or resistance between the various forms of masculinity within a given communication community. Second, there is the process whereby access to the mechanisms that allow men to identify themselves with those masculinities is unequally distributed among members of that communication community. Third, there is the process by which the performance of a particular masculinity is accorded recognition by others; unless the community can identify a man's performance as one of an acknowledged repertoire of masculinities then his social position will remain uncertain at best. Once again, the role of communication communities as communities of interpretation is important here, and particular forms of masculinity might be accorded very different kinds of recognition by different communication communities. It is at this point, for instance, that considerations of ethnicity frequently influence the place of minorities within relations of power: for example, communities frequently fail to acknowledge the legitimacy of performances of prestigious forms of masculinity by immigrant men, whereas those same men might enjoy high status within another communication community. Queer gender identities, as when women perform masculinities, are also frequently positioned in power relations at this stage if those performances are not recognised as conforming to the cultural stereotype within a particular communication community. ${ }^{102}$ The fourth operation of power occurs after this process of recognition: having been identified with a particular form of masculinity, the individual is then positioned in relation to sets of institutional practices, rewards and sanctions. It is at this stage, for example, that men are granted the status of village elder or voter, or that the Child Support Agency becomes entitled to enforce certain paternal duties. In this way, cultural, social and 
political histories of masculinity interact dynamically to produce a complicated web of power relations between masculinities and, ultimately, between men.

In this framework the state may feature at multiple points as a significant institution, but it is worth underlining that the state cannot be seen straightforwardly as the instrument of hegemonic masculinity or the tool of a particular communication community. Work conducted in the wake of Catherine MacKinnon's Towards a feminist theory of the state has shown that the state should be seen as a series of sites in which gendered interests are both constructed and contested, rather than a monolithic entity which represents 'male' interests. ${ }^{103}$ When state policy has been guided by the norms of particular communication communities, sanctions might have been imposed on forms of male conduct deemed perfectly acceptable within other communication communities. The fierce arguments over compulsory schooling and compulsory vaccination of children in the nineteenth century are perhaps best understood in this light as symptoms of a clash between communities that held very different understandings of parenting. ${ }^{104}$ Legislation against drunkenness, wifebeating, and speeding might be seen in the same light.

Studying the four-fold operation of power in this way would produce a history of masculinity sensitive to the power relations between masculinities without falling prey to many of the problems associated with Connell's model. It would enable us to integrate the study of gender hierarchies with other forms of social stratification like class, ethnicity, age and disability. The same set of processes may be taken to have occurred in the relationships between different models of femininity. The power relationships that emerged between men and women will have been fundamentally shaped by these processes but Connell's claim that there is a functional relationship between the two patterns of inequalities must be demonstrated empirically rather than assumed a priori. 


\section{Subjectivity and the situational identity problem}

This leaves us with situational identity problem, whereby men move between different forms of masculinity in the course of daily interactions. As we have seen, this problem raises important questions about agency and subjectivity. The approach suggested above has already dealt in large part with the question of agency. Individuals were frequently socialized into multiple variants of masculinity by virtue of participation in multiple communication communities, each with different sets of norms, and individuals might have had access to resources that allowed them to identify themselves with several different forms of masculinity. But men (and women) were not free to adopt any masculinity that they liked. Furthermore, we should not see this process of identification as in any sense a matter of conscious choice by an individual; because to do so would be to presuppose the existence of a conscious self that exists prior to the performance of gender. As Judith Butler has argued, drawing on Foucault, the self is constituted through these performative acts and within these relations of power - it does not exist independently of them. ${ }^{105}$ This merely underlines the utility of Bourdieu's concept of habitus, which is a way of describing how individuals subconsciously develop a level of cultural competence that allows them to behave appropriately in different social settings: exercising agency within the frame of a set of structured dispositions. ${ }^{106}$

But within this frame, how did an individual develop a sense of self and make sense of his or her own gender performances? In other words, how can we deal with the problems that the situational identity problem poses for historians interested in subjectivities? ${ }^{107}$ How did individuals experience the shifts that they made between masculinities? How did the solider experience the transition from the martial masculinity of the parade ground to the domesticated 
masculinity he practised at home? Did he perceive a sharp divide between the professional and personal masculinities he performed, or did he see them as expressions of a coherent self? Such questions need to be asked if we are to move beyond a history of masculinity oriented around a history of cultural stereotypes. One of the major deficiencies of Connell's theory of hegemonic masculinity is that it offers no way of explaining how individuals internalise forms of masculinity, and any adequate explanatory framework must address this point. ${ }^{108}$

Social psychology is a discipline that has grappled explicitly with the idea that 'we may have many selves, and ... contextual factors can bring different selves into play'. ${ }^{109}$ The literature on identity and 'the kaleidoscopic self' has taken an interest in precisely this question of how individuals move between different context-specific identities while constructing a self that is not so fragmented as to become dysfunctional. ${ }^{110}$ Of the many different approaches explored by social psychologists, perhaps the most compatible with a historical understanding of the problem has been set out by Margaret Wetherell and Nigel Edley. ${ }^{111}$ They are interested in examining the rhetorical strategies that men use to position themselves relative to hegemonic forms of masculinity when talking about their lives: a process that they describe as imaginary positioning. Their study found, for example, that it was rare for interviewees to adopt a persona that one might associate with hegemonic masculinity; it was much more common for interviewees to emphasize 'the ordinariness of self; the self as normal, moderate or average', or to identify themselves as rebelling against hegemonic norms. ${ }^{112} \mathrm{~A}$ weakness of this study is its lack of historical specificity: the authors take for granted the characteristics that they ascribe to hegemonic masculinity without acknowledging that those values are subject to change. Nor do they consider the degree of dissonance between their own understanding of hegemonic values and those of their interviewees. Nevertheless, it is straightforward to imagine how historians 
might study the rhetorical strategies that people in the past used to engage in imaginary positioning.

The most sophisticated approach to the complexity of masculine subjectivities, however, and the most historically sensitive, has derived from Graham Dawson's book Soldier heroes, which uses a conceptual toolkit derived from Kleinian psychoanalysis rather than social psychology. Dawson argues that 'the achievement of an absolutely unified and coherent gendered social identity, for masculinity as for femininity, is an impossibility', because 'the demands and recognitions of social life are not uniform but many-faceted and contradictory'. ${ }^{113}$ Consequently, individuals find themselves 'striving, not only for a formally satisfying narrative or a coherent version of events, but also for a version of the self that can be lived with in relative psychic comfort - for, that is, subjective composure.' Individuals searching for that composure are necessarily constrained by the 'narrative resources of a culture - its repertoire of shared and recognized forms.' They are also constrained by the fact that within a given cultural system certain forms of masculinity, and even 'the demand or desire for certain kinds of coherence and unity' 'are installed as more appropriate and recognizable than others'. Furthermore, subjective composure 'fundamentally depends on social recognition, with its power to confirm that the versions of self and world configured in a narrative [of self] correspond to those of other people'. This underlines the importance of communication communities as sites of interpretation: the recognition accorded by different audiences 'exercises a determining influence upon the way a narrative may be told and, therefore, upon the kind of composure that it makes possible.' In other words, individuals are not only constrained in the masculinities that they can perform, they are also constrained in the ways in which they can make sense of their gender performances.

The concept of subjective composure has received considerable attention from historians of memory, especially practitioners of oral history. This is despite the fact that processes of 
composure are not confined to tasks of explicit memory-work like writing memoirs or being interviewed about one's life-history; they are present in all manner of quotidian activities and interactions as individuals construct a self. Historians have been particularly concerned to emphasise the ways in which discomposure might be as likely to accompany the creation of lifestories as composure. ${ }^{114}$ For present purposes, the significance of these moments of discomposure - moments of unease or contradiction in personal accounts of life histories - is that they render visible to historical analysis the difficulties that individuals face in making sense of their multiple masculinities. Penny Summerfield has identified three possible reasons for such discomposure in oral history interviews: clashes between the ways in which interviewers frame their research and the ways in which interviewees frame their memories; conflicts between identities constructed for public display and more private constructions of the self; and non-verbal interpersonal dynamics between interviewer and interviewee. ${ }^{115}$ In the light of the analysis above, we can see that Summerfield's list presents special cases of broader phenomena. Discomposure might result from the situational identity problem - the need to construct multiple identities in order to negotiate the power structures within communication communities, the transitions between communication communities, or the various demands of audiences capable of conferring social recognition on gender performances. It might also result from an individual's limited access to the cultural resources best suited to effect subjective composure in any given situation. It might also be caused by the many internal contradictions which historians have identified within normative codes of masculinity. ${ }^{116}$

Consequently, we can see how subjectivities are created (and unsettled) in the context of the broader pattern of power relations set out above. It needs to be stressed, however, that this gains us only a partial view of subjectivity which, as Michael Roper has argued, is not 'wholly composed by ideological formations - competing, contradictory, or otherwise - but [is] a matter 
of personality formed through lived experiences and the emotional responses to those experiences. ${ }^{, 117}$ Interiority in that sense may be best studied using concepts from psychoanalysis, or by means of approaches pioneered by historians of emotions. Nevertheless, the experiences and imaginative resources which individuals imbue with affective meanings will bear the traces of the four-fold operation of power described above.

\section{Conclusion}

This article has defended the idea that it is meaningful to take as the subject of historical inquiry power relations between masculinities. Although Raewyn Connell's model is beset by problems, it remains meaningful to say that certain normative models of masculinity were dominant within particular communication communities and that others were complicit with that dominance, subordinated, or marginalised. It also remains possible to describe historically contests for power and influence between competing models of masculinity and the institutions implicated in those struggles. Those struggles took place within and between communication communities. In order to connect those contested relations, which were principally cultural, to the lived experience of men, we need to study historically the strategies and techniques that men used to appropriate and identify themselves with particular masculinities. On that basis, I have suggested that power can be apprehended as a four-fold operation: cultural contestation of ideal types; individual attempts to identify with those cultural types; processes by which those attempts are accorded recognition by others; and processes by which individuals are positioned in relation to institutional practices, rewards and sanctions. Thinking about the history of masculinity in this way will allow for meaningful generalisations about change over time, and will produce more incisive periodisation, without losing sight of the complexity of gender relations. 
What kind of research agenda would this approach produce? This might be presented most easily by a list of questions. First, what cultural forms of masculinity were available in any given communication community? Second, what institutions or practices authorised forms of masculinity in a given community and how did they change over time? Third, what pattern of relationships did this produce between cultural forms of masculinity, both within and between communication communities? Fourth, what historically specific techniques or mechanisms allowed individuals to appropriate the qualities associated with particular masculinities? Fifth, how did individuals negotiate movement between masculinities? Sixth, what historically specific strategies were available to individuals as they sought subjective composure, and what might this tell us about the ways in which masculinity was experienced? Seventh, were there significant changes in the composition of the relevant communication communities? And finally, what impact did these various developments have on formal political struggles?

As an analytical framework this must necessarily be incomplete, and it certainly bears little resemblance to Connell's original model, but it does have the advantage of highlighting the centrality of power relations between masculinities to the history of gender. The widespread scepticism about Connell's model ought not to lead us to reject or ignore efforts to place those relations at the heart of the history of masculinity as the field enters its next phase.

\footnotetext{
1 Joan Scott, 'Gender: a useful category of historical analysis', American Historical Review 91 (1986), pp. 1053-75.

${ }^{2}$ Anna Clark, 'Gender, class and the nation: franchise reform in England, 1832-1928' in James Vernon, ed., Re-reading the constitution (Cambridge: Cambridge University Press, 1996), pp. 62-88; Matthew McCormack, "Married men and the fathers of families": fatherhood and franchise reform in Britain', in Trev Lynn Broughton and Helen Rogers, eds., Gender and fatherhood in the nineteenth century (Basingstoke: Palgrave Macmillan, 2007), pp. 43-54; Ben Griffin, The politics of gender in Victorian Britain: masculinity, political culture and the struggle for women's rights (Cambridge: Cambridge University Press, 2012), ch. 7-10.

${ }^{3}$ For good examples of this trope's importance see Matthew McCormack, 'The new militia: war, politics and gender in 1750s Britain' Gender and History 19 (2007), pp. 483-500.
} 
${ }^{4}$ R. W. Connell and J. W. Messerschmidt, 'Hegemonic masculinity: rethinking the concept', Gender and Society 19 (2005), p. 845.

${ }^{5}$ R. W. Connell, Masculinities (Cambridge: Polity, 1995); Connell and Messerschmidt, 'Hegemonic masculinity', pp. 829-59.

${ }^{6}$ L. E. Klein, Shaftesbury and the culture of politeness (Cambridge: Cambridge University Press, 1994); Philip Carter, Men and the emergence of polite society, Britain 1660-1800 (London: Routledge, 2001); Michèle Cohen, "Manners" make the man: politeness, chivalry, and the construction of masculinity, 1750-1830', Journal of British Studies 44 (2005), p. 326; John Tosh, 'The old Adam and the new man: emerging themes in the history of English masculinities, 1750-1850' in Tim Hitchcock and Michèle Cohen, eds., English masculinities, 1660-1800 (London: Routledge, 1999), pp. 217-38; idem, 'Gentlemanly politeness and manly simplicity in Victorian England', Royal Historical Society Transactions, sixth series, vol. 12 (2003), pp. 455-72; Boyd Hilton, 'Manliness, masculinity and the mid-Victorian temperament' in Lawrence Goldman, ed. The blind Victorian: Henry Fawcett and British Liberalism (Cambridge: Cambridge University Press, 1989), pp. 60-70; Stefan Collini, Public moralists: political thought and intellectual life in Britain, 1850-1930 (Oxford: Oxford University Press, 1991), ch. 5; John Tosh, A man's place. Masculinity and the middle class home in Victorian England (London: Yale University Press, 1999); Martin Francis, 'The domestication of the male? Recent research on nineteenth and twentieth-century British masculinity', Historical Journal 45 (2002), pp. 637-52.

${ }^{7}$ Karen Harvey, 'The history of masculinity, circa 1650-1800', Journal of British Studies 44 (2005), pp. 296311; Alexandra Shepard, 'From anxious patriarchs to refined gentlemen? Manhood in Britain, circa 15001700', ibid, p. 288; Henry French and Mark Rothery, Man's estate: landed gentry masculinities, 1660-1900 (Oxford: Oxford University Press, 2012).

${ }^{8}$ Michael Kimmel, 'The contemporary "crisis of masculinity" in historical perspective' in Harry Brod, ed., The making of masculinities (Boston: Allen and Unwin, 1987). Elaine Showalter, Sexual anarchy: gender and culture at the fin de siècle (London: Virago, 1991); Judith Allen, 'Men interminably in crisis?' Radical History Review 82 (2002), pp. 191-207.

${ }^{9}$ John Tosh, 'What should historians do with masculinity? Reflections on nineteenth century Britain', History Workshop Journal 38 (1994), pp. 179-202; idem, 'Hegemonic masculinity and the history of gender', in Stefan Dudink, Karen Hagermann and John Tosh, eds., Masculinities in politics and war: gendering modern history (Manchester: Manchester University Press, 2004), p. 41.

${ }^{10}$ Karen Harvey and Alexandra Shepard, 'What have historians done with masculinity? Reflections on five centuries of British history, c. 1500-1950', Journal of British Studies 44 (2005), pp. 275-6; John Tosh, 'The history of masculinity: an outdated concept', in John Arnold and Sean Brady, What is masculinity? Historical dynamics from antiquity to the contemporary world (Basingstoke: Palgrave Macmillan, 2011), p. 24; John Tosh, 'Home and away: the flight from domesticity in late-nineteenth-century England re-visited', Gender and History 27 (2015), pp. 561-575.

${ }^{11}$ Judith Bennett, History matters: patriarchy and the challenge of feminism (Philadelphia: University of Pennsylvania Press, 2006), pp. 54-82.

${ }^{12}$ R. W. Connell, Gender and power (Cambridge: Polity, 1987), pp. 183-8; Connell, Masculinities, pp. 76-81; Connell and Messerschmidt, 'Hegemonic masculinity'.

${ }^{13}$ Simon Yarrow, 'Masculinity as a world historical category of analysis' in John Arnold and Sean Brady, What is masculinity?, p. 121.

${ }^{14}$ E. g. Michèle Cohen, “"Manners” make the man', p. 313. William Stafford argues that, because more than one form of masculinity can be found among the social elite, 'there was not a single, coherent "hegemonic" masculinity at this time'. This sets the standard of proof higher than any human society could reach. William Stafford, 'Gentlemanly masculinities as represented by the late Georgian Gentleman's Magazine', History 93 (2008), p. 61. Stafford's analysis is confused by a reluctance to distinguish between 'masculinity' and historically specific codes of 'manhood' or 'manliness'. Cf. Connell and Messerschmidt, 'Hegemonic masculinity', pp. 845, 850.

${ }^{15}$ Connell, Masculinities, p. 77.

${ }^{16}$ Connell, Masculinities, pp. 73-6; R. W. Connell, Gender (Cambridge: Polity, $2^{\text {nd }}$ ed., 2009), pp. 76-85.

${ }^{17}$ Sofia Aboim, Plural masculinities: the remaking of the self in private life (Farnham: Ashgate, 2010), p. 45.

${ }^{18}$ Connell and Messerschmidt, 'Hegemonic masculinity', p. 844. Emphasis added. 
${ }^{19}$ Connell, Gender and power, ch. 7; idem, Masculinities, ch. 8. For a useful critique see French and Rothery, Man's estate, pp. 8-9.

${ }^{20}$ Futoshi Taga, 'Rethinking Japanese masculinities' in Mark McLelland and Romit Dasgupta, Genders, transgenders and sexualities in Japan (London: Routledge, 2005), p. 160; Jason G. Karlin, 'The gender of nationalism: competing masculinities in Meiji Japan' Journal of Japanese Studies 28 (2002), pp. 41-77. ${ }^{21}$ Michael Kimmel, Manhood in America: a cultural history (Oxford, Oxford University Press, $1^{\text {st }}$ ed., 1996; $2^{\text {nd }}$ ed, 2006); Karen Hagemann, 'German heroes: the cult of the death for the fatherland in nineteenthcentury Germany', in Dudink, Hagermann and Tosh, eds., Masculinities in politics and war, p. 124.

22 Stefan Dudink and Karen Hagemann, 'Masculinity in politics and war in the age of democratic revolutions, 1750-1850' in Dudink, Hagermann and Tosh, eds., Masculinities in politics and war, p. 5. ${ }^{23}$ Connell, Masculinities, p. 84.

${ }^{24}$ E.g. Henry French and Mark Rothery, Man's estate; see my review in English Historical Review 128 (2013), pp. 1591-3.

${ }^{25}$ Connell, Masculinities, p. 73.

${ }^{26}$ John Tosh, 'Hegemonic masculinity and the history of gender', in Dudink, Hagermann and Tosh, eds., Masculinities in politics and war, p. 54.

${ }^{27}$ Connell, Masculinities, pp. 80-1.

${ }^{28}$ Tosh, 'Hegemonic masculinity and the history of gender', pp. 53-4.

${ }^{29}$ Connell, Masculinities, p. 77.

${ }^{30}$ The best defence of functionalist explanations in the social sciences is G. A. Cohen, Karl Marx's theory of history: a defence (Oxford: Oxford University Press, $2^{\text {nd }}$ ed., 2001), ch. 9. The clearest statement of scepticism remains Anthony Giddens, The constitution of society (Cambridge: Polity, 1984), pp. 293-7. A good overview is J. Holmwood, 'Functionalism and its critics' in A. Harrington, ed., Modern social theory: an introduction (Oxford: Oxford University Press, 2005), pp. 87-109. The ontological criticism of functionalism - that a society cannot have 'needs' - has been given a further twist by Actor Network Theory: see Bruno Latour, Reassembling the social: an introduction to Actor Network Theory (Oxford: Oxford University Press, 2005).

31 Jeff Hearn, 'From hegemonic masculinity to the hegemony of men', Feminist Theory 5 (2004), pp. 49-72.

32 Connell, Gender and power, p. 187.

33 E.g. Beverley Skeggs, Formations of class and gender: becoming respectable (London: Sage, 1997).

${ }^{34}$ Mimi Schippers, 'Recovering the feminine other: masculinity, femininity, and gender hegemony', Theory and Society 36 (2007), p. 94.

35 Schippers, 'Recovering the feminine other', p. 95.

${ }^{36}$ Schippers, 'Recovering the feminine other', p. 95.

${ }^{37}$ Connell, Gender and power, ch. 5-6.

${ }^{38}$ See Perry Anderson, 'The antinomies of Antonio Gramsci', New Left Review 100 (1976).

${ }^{39}$ Richard Howson, Challenging hegemonic masculinity (London, Routledge, 2006); Demetrakis Z.

Demetriou, 'Connell's concept of hegemonic masculinity: a critique', Theory and Society 30 (2001), pp.

337-61.

${ }^{40}$ Alexandra Shepard, Meanings of manhood in early modern England (Oxford: Oxford University Press, 2003), p. 250.

${ }^{41}$ Shepard, 'From anxious patriarchs to refined gentlemen?', p. 291.

42 I am grateful to Alastair Reid for his criticisms of an earlier draft of this paragraph.

${ }^{43}$ Connell and Messerschmidt, 'Hegemonic masculinity: rethinking the concept', p. 849-50.

${ }^{44}$ Cf. Marilyn Strathern, Partial connections (Walnut Creek, CA: Altamira Press, 2005).

45 Patrick Joyce, Visions of the people: industrial England and the question of class, 1848-1914 (Cambridge: Cambridge University Press, 1991), ch. 11-14; David Vincent, Literacy and popular culture, England 17501914 (Cambridge: Cambridge University Press, 1989).

${ }^{46}$ Simon Szreter, Fertility, class and gender in Britain 1860-1940, (Cambridge: Cambridge University Press, 1995), pp. 546-9; Simon Szreter and Kate Fisher, 'Love and authority in mid-twentieth century marriage: sharing and caring', in L. Delap, B. Griffin and A. Wills, eds., The Politics of Domestic Authority in Britain, 1800-2000 (Basingstoke: Palgrave Macmillan, 2009), pp. 132-54; Siân Pooley, 'Child care and neglect: a comparative local study of late nineteenth century parental authority', ibid, pp. 223-42. 
${ }^{47}$ Mike Donaldson, 'What is hegemonic masculinity?', Theory and Society 22 (1993), pp. 643-57.

${ }^{48}$ Connell, Gender and power, pp. 184-5.

${ }^{49}$ Connell, Masculinities, p. 77.

${ }^{50}$ Robert A. Nye, Masculinity and male codes of honour in modern France (Berkley: University of California Press, 1993), p. 13.

${ }^{51}$ Christopher E. Forth and Bertrand Taithe, French masculinities: history, culture and politics (Basingstoke: Palgrave Macmillan, 2007), p. 4; cf. Griffin, The politics of gender, ch. 6.

52 Joan W. Scott: "Millenial fantasies": the future of 'gender' in the 21st Century', L'Homme. Zeitschrift fuer Feministische Geschichtswissenschaft 13 (2002); John Tosh, 'The history of masculinity: an outdated concept', pp. 23-5; Harvey and Shepard, 'What have historians done with masculinity?', p. 276.

${ }^{53}$ R. W. Connell, 'Politics of changing men', Arena 6 (1996), p. 56.

${ }^{54}$ Connell and Messerschmidt, 'Hegemonic masculinity', p. 842.

${ }^{55}$ Schippers, 'Recovering the feminine other', p. 93.

${ }^{56}$ Shepard, 'From anxious patriarchs to refined gentlemen?', p. 291.

${ }^{57}$ Kate Davison, 'Occasional politeness and gentlemen's laughter in 18th c England', Historical Journal 57 (2014), pp. 921-45.

${ }^{58}$ Philip Carter, 'James Boswell's manliness' in Hitchcock and Cohen, eds., English masculinities, pp. 12930.

${ }^{59}$ Margaret Wetherell and Nigel Edley, 'Negotiating hegemonic masculinity: imaginary positions and psycho-discursive practices' Feminism and psychology 9 (1999), pp. 335-56.

${ }^{60}$ Jeff Hearn, 'From hegemonic masculinity to the hegemony of men', Feminist Theory 5 (2004), pp. 97120.

${ }^{61}$ Michael Roper, 'Slipping out of view: subjectivity and emotion in gender history,' History Workshop Journal 59 (2005), pp. 57-72.

${ }^{62}$ Szreter, Fertility, class and gender, pp. 546-9. See also Griffin, Delap and Wills, The politics of domestic authority, p. 12.

${ }^{63}$ Bertrand Taithe, 'Neighbourhood boys and men: the changing spaces of masculine identity in France, 1848-71' in Forth and Taithe, French masculinities, p. 69.

${ }^{64}$ Simon Szreter, Fertility, class and gender, pp. 488-503; Szreter and Fisher, 'Love and authority', pp. 13254; Siân Pooley, 'Child care and neglect', pp. 223-42.

${ }^{65}$ Szreter, Fertility, class and gender, p. 552; R. J. Morris, Men, women and property in England, 1780-1870 (Cambridge: Cambridge University Press, 2005), p. 342. W. D. Rubinstein, 'Education and the social origins of British elites, 1880-1970', Past and Present 112 (1986), pp. 173-5.

${ }^{66}$ For studies of immigrant communities that could be reframed in this way, see the chapters by Susan L. Tananbaum and Amanullah De Sondy in Lucy Delap and Sue Morgan, eds., Men, masculinities and religious change in twentieth-century Britain (Basingstoke: Palgrave Macmillan, 2013).

${ }^{67}$ C.A. Bayly, The birth of the modern world (Oxford: Blackwell, 2004), pp. 12-17.

${ }^{68}$ Pierre Bourdieu, Outline of a theory of practice (Cambridge: Cambridge University Press, 1977), p. 72.

${ }^{69}$ Pierre Bourdieu, Distinction: a social critique of the judgement of taste (London: Routledge, 1984), p. 91.

${ }^{70}$ For critical commentary on Bourdieu's handling of gender, see Lois McNay, 'Gender, habitus and the field: Pierre Bourdieu and the limits of reflexivity', Theory, Culture and Society 16 (1999), pp. 95-117; L. Adkins, ed., Feminists after Bourdieu: international perspectives (Oxford: Blackwell, 2004).

${ }^{71}$ Michael Curtin, Propriety and position, a study of Victorian manners (New York: Garland, 1987), pp. 11415. See also Griffin, Politics of gender, pp. 190-3. Cf. Christopher E. Forth, The Dreyfus Affair and the crisis of French manhood (Baltimore: Johns Hopkins University Press, 2004), pp. 24-33.

${ }^{72}$ Peter Mandler, 'The problem with cultural history', Cultural and Social History 1 (2004), pp. 96-7.

${ }^{73}$ Harvey and Shepard, 'What have historians done with masculinity?', p. 277.

${ }^{74}$ Graham Dawson, Soldier heroes: British adventure, empire and the imagining of masculinities (London: Routledge, 1994), p. 23.

${ }^{75}$ J. R. de S. Honey, Tom Brown's Universe: the development of the public school in the $19^{\text {th }}$ century (New York: Quadrangle, 1977); J. A. Mangan and James Walvin, eds., Manliness and morality: middle class masculinity in Britain and America, 1800-1940 (Manchester: Manchester University Press, 1987). On rough music and gossip see Anna Clark, The struggle for the breeches: gender and the making of the 
British working class (Berkeley: University of California Press, 1995); A. James Hammerton, Cruelty and companionship: conflict in nineteenth century married life (London: Routledge, 1992); Ellen Ross, " $F i e r c e$ questions and taunts": married life in working class London, 1870-1914', Feminist Studies 8 (1982), pp. 575-602; idem, "Not the sort that would sit on the doorstep": respectability in pre-World War I London neighbourhoods', International Labour and Working Class History 27 (1985), pp. 39-59.

${ }^{76}$ Matthew Gutmann, The meanings of macho: being a man in Mexico City (Berkeley: University of California Press, 1996), pp. 83-6.

77 Michael Roper, Masculinity and the British organisation man since 1945 (Oxford: Oxford University Press, 1994), p. 105.

${ }^{78}$ Roper, Masculinity and the British organisation man, p. 119.

${ }^{79}$ Simon Yarrow, 'Masculinity as a world historical category of analysis' in John Arnold and Sean Brady, What is masculinity?, p. 122.

${ }^{80} \mathrm{Ibid}, \mathrm{p} .122$.

81 Ibid, p. 122.

${ }^{82}$ Stuart Hall, 'Cultural identity and diaspora', in Jonathan Rutherford, ed., Identity, community, culture, difference (London: Lawrence \& Wishart, 1990), p. 222.

${ }^{83} \mathrm{~A}$ similar approach is advocated by Michael Kimmel in 'Masculinity as homophobia: fear, shame and silence in the construction of gender identity' in Harry Brod and Michael Kaufman, eds., Theorizing masculinities (London: Sage, 1994), p. 125.

${ }^{84}$ Griffin, The politics of gender, ch. 6.

${ }^{85} \mathrm{Cf}$. Erving Goffman, The presentation of self in everyday life (New York: Doubleday Anchor, 1959). The same point is made in Christopher E. Forth, Masculinity in the Modern West: gender, civilization and the body (Basingstoke: Palgrave Macmillan, 2008), p. 55.

${ }^{86}$ Szreter, Fertility, class and gender, pp. 520-1.

${ }^{87}$ Forth, Masculinity in the Modern West, pp. 177-9; Matthew Hilton, Smoking in British popular culture 1800-2000 (Manchester: Manchester University Press, 2000), ch. 5-6.

${ }^{88}$ Ute Frevert, 'Bourgeois honour: middle-class duellists in Germany from the late eighteenth to the early twentieth century' in David Blackbourn and Richard J. Evans, eds., The German bourgeoisie (London: Routledge, 1991), p. 279; Jonathan Steinberg, Bismarck, a life (Oxford: Oxford University Press, 2011), p. 41.

${ }^{89}$ Linda Colley, Britons: forging the nation, 1708-1837 (London: Yale University Press, 1992), p. 303.

${ }^{90}$ E. g. Kimmel, Manhood in America, pp. 132-3.

${ }^{91}$ Penny Summerfield, ed., Women, education and the professions (Leicester: History of Education society, 1987); Carol Dyhouse, 'Women Students and the London Medical Schools 1914-3: the anatomy of a masculine culture', Gender and History 10 (1998), pp. 110-32; R. Auchmuty, 'Whatever happened to Miss Bebb? Bebb v. the Law Society and women's legal history', 31 Legal Studies (2011), pp. 199-230; Ulrike Schultz and Gisela Shaw, eds., Women in the world's legal professions (Oxford: Hart, 2003).

${ }^{92}$ Harold Perkin, The rise of professional society: England since 1880 (London: Routledge, 1989), p. 20.

${ }_{93}$ Roper, The British organization man, p. 112.

${ }^{94}$ Kimmel, 'Masculinity as homophobia', p. 125.

${ }_{95}$ John B. Thompson, Studies in the theory of ideology (Cambridge: Polity, 1984), p. 61.

${ }^{96} \mathrm{Cf}$. Gill Valentine, 'What it means to be a man: the body, masculinities, disability' in Ruth Butler and Hester Parr, eds., Mind and body spaces: geographies of disability, illness and impairment (London:

Routledge, 1999), pp. 167-80.

${ }^{97}$ Connell, Gender and power, p. 85. Cf. Judith Butler, Gender trouble (2007 ed.), pp. 10, 191.

${ }^{98}$ Roper, The British organization man, p. 108.

${ }^{99}$ Michael Braddick, ed., The politics of gesture: historical perspectives (Oxford: Oxford University Press, 2009) [Past and Present 203 supplement 4].

100 Henry Lucy, A diary of two parliaments. The Disraeli Parliament, 1874-1880 (London: Cassell, 1885), pp. 102-3.

${ }^{101}$ Griffin, Politics of gender, pp. 190-3. 
${ }^{102}$ For examples, see Alison Oram, Her husband was a woman! Women's gender-crossing in modern British popular culture (London: Routledge, 2007); Judith Halberstam, Female masculinity (Durham, NC: Duke University Press, 1998).

${ }^{103}$ Catherine MacKinnon, Towards a feminist theory of the state (Cambridge, Mass.: Harvard University Press, 1989); S. Franzway, D. Court, and R. W. Connell, Staking a claim: feminism, bureaucracy and the state (Cambridge: Polity, 1989), pp. 42-3, 52; R. W. Connell, 'The state, gender and sexual politics: theory and appraisal', Theory and Society 19 (1990), pp. 507-44.

${ }^{104}$ Siân Pooley, "'All we parents want is that our children's health and lives should be regarded": child health and parental concern in England, c.1860-1910', Social History of Medicine 23 (2010), pp. 528-48. 105 Judith Butler, Bodies that matter (London: Routledge, 1993), p. 15.

${ }^{106}$ See the useful discussion of this point in Davison, 'Occasional politeness', pp. 922-3. Butler, Gender trouble (London: Routledge, 2007 ed. with 1999 preface), p. xv.

${ }^{107}$ Michael Roper, 'Slipping out of view: subjectivity and emotion in gender history,' History Workshop Journal 59 (2005): 57-72.

${ }^{108}$ Margaret Wetherell and Nigel Edley, 'Negotiating hegemonic masculinity: imaginary positions and psycho-discursive practices' Feminism and psychology 9 (1999), pp. 335-56; cf. Connell and

Messerschmidt, 'Hegemonic masculinity', p. 842.

${ }^{109}$ Michael A. Hogg and Graham M. Vaughan, Social psychology (4th ed., Harlow: Pearson, 2005), p. 126. Cf. Cecilia Ridgeway, 'Linking social structure and interpersonal behaviour: a theoretical perspective on cultural schemas and social relations', Social Psychology Quarterly 69 (2006), pp. 5-16.

${ }^{110} \mathrm{~K}$. Deaux and J. S. Perkins, 'The kaleidoscopic self' in C. Sedikides and M. B. Brewer, eds., Individual self, relational self, collective self (Philadelphia: Psychology Press, 2001). An important early statement was Seymour Rosenberg and Michael Gara, 'The multiplicity of personal identity', Review of Personality and Social Psychology 6 (1985), pp. 87-113. For a summary of various approaches, see Kay Deaux and Daniela Martin, 'Interpersonal networks and social categories: specifying levels of context in identity processes', Social Psychology Quarterly 66 (2003), pp. 101-17. This literature has been slow to grapple with gender, usually taking the term to mean simply differences between men and women rather than anything more nuanced.

${ }^{111}$ Wetherell and Edley, 'Negotiating hegemonic masculinity'. For alternative frameworks, see Sheldon Stryker and Peter J. Burke, 'The past, present and future of an identity theory', Social Psychology Quarterly 63.4 (2000), pp. 284-97; or Sonia Roccas and Marilynn Brewer, 'Social identity complexity' Personality and Social Psychology Review 6 (2002), pp. 88-106.

${ }^{112}$ Wetherell and Edley, 'Negotiating hegemonic masculinity', pp. 342-3, 347.

${ }^{113}$ All of the quotations from Dawson that follow are taken from Dawson, Soldier heroes, pp. 23-4.

114 'Dis/ composing the subject: intersubjectivities in oral history', in Tess Cosslett, Celia Lury and Penny Summerfield, eds., Feminism and autobiography: texts, theories, methods (London: Routledge, 2000), pp. 91-106; idem, 'Culture and composure: creating narratives of the gendered self in oral history interviews', Cultural and Social History 1 (2004), pp. 65-93; Michael Roper, 'Re-remembering the soldier hero: the psychic and social construction of memory in personal narratives of the Great War', History Workshop Journal 50 (2000), pp. 181-204; Juliette Pattinson, “"The thing that made me hesitate ...": re-examining gendered intersubjectivities in interviews with British secret war veterans', Women's History Review 20 (2011), pp. 245-63; Marlene Briggs, 'Dis/composing the First World War in Britain: Trauma and Commemoration in the Testimony of Harry Patch, 1998-2008' History and Memory 28 (2016), pp. 79-109.

${ }^{115}$ Summerfield, 'Dis/ composing the subject', p. 94.

${ }^{116}$ Summerfield, 'Culture and composure', pp. 70-1; idem. 'Dis/ composing the subject', pp. 100-102.

${ }^{117}$ Roper, 'Slipping out of view', p. 65. 